Sari Pediatri, Vol. 7, No. 1, Juni 2005: 26-33

\title{
Masalah pada Tata Laksana Anemia Aplastik Didapat
}

\author{
Isyanto, Maria Abdulsalam
}

Anemia aplastik adalah kegagalan sumsum tulang baik secara fisiologis maupun anatomis. Penyakit ini ditandai oleh penurunan atau tidak ada faktor pembentuk sel darah dalam sumsum tulang, pansitopenia darah perifer, tanpa disertai hepatosplenomegali atau limfadenopati. Penanganan anemia aplastik masih merupakan masalah yang penting karena patofisiologi penyakit ini masih belum pasti. Tata laksana anemia aplastik terdiri dari tata laksana suportif terhadap keadaan yang disebabkan oleh pansitopenia seperti anemia, infeksi dan perdarahan, serta tata laksana serta pengobatan yang bertujuan untuk mengganti sel induk yang gagal dalam memproduksi sel-sel darah dan menekan proses imunologis yang terjadi. Tata laksana kuratif terdiri dan transplantasi sumsum tulang dan penggunaan obat-obat imunosupresan. Namun demikian tata laksana anemia aplastik baik yang bersifat suportif maupun kuratif, dapat menimbulkan masalah-masalah yang mempengaruhi prognosis pasien. Prognosis pasien anemia aplastik umumnya buruk, sekitar dua pertiga pasien meninggal setelah 6 bulan diagnosis ditegakkan sebagai anemia aplastik.

Kata kunci: acquired aplastic anemia, bone marrow transplantation, immunosupression.

p nyakit anemia aplastik pertama kali di deskripsikan oleh Ehrlich tahun 1888, sampai sekarang penyakit ini mempunyai reputasi yang rnenakutkan. Banyak pasien anemia aplastik meninggal karena proses penyakitnya yang progresif. ${ }^{1-2}$ Dasar penyakit ini adalah kegagalan sumsum tulang dalam memproduksi sel-sel hematopoetik dan limfopoetik, yang mengakibatkan tidak ada atau berkurangnya sel-sel darah di darah tepi, keadaan ini disebut sebagai pansitopenia. ${ }^{1,3-4}$

Pada tujuh puluh persen kasus penyebab anemia aplastik didapat tidak dapat diterangkan, sedangkan sisanya diduga akibat radiasi, bahan kimia termasuk

\footnotetext{
Alamat korespondensi: Dr Maria Abdulsalam, Sp.A(K).

Divisi Hematologi-onkologi. Departemen Ilmu Kesehatan Anak FKUIRSCM, Jakarta.

Jl. Salemba no. 6, Jakarta 10430

Telepon: 021-3907744, 31901170 Fax.021-3913982.
}

Dr. Isyanto. PPDS Ilmu Kesehatan Anak FKUI, Jakarta. obat-obatan, infeksi virus, dan lain-lain. ${ }^{5}$ Gejala-gejala yang timbul pada pasien anemia aplastik merupakan gejala pansitopenia seperti pucat, perdarahan, dan infeksi. Etiologi penyakit ini kebanyakan tidak diketahui maka tata laksananya juga belum optimal dan seringkali menimbulkan masalah-masalah baru pada pasien, bukan hanya memperburuk kondisi pasien atau bahkan dapat mengancam jiwa pasien.

Tulisan ini bertujuan untuk membahas tentang tata laksana anemia aplastik dan masalah yang mungkin timbul.

\section{Insidens Anemia Aplastik}

Anemia aplastik merupakan penyakit yang jarang ditemukan di dunia. Angka kejadian di Asia termasuk Cina, Jepang, Thailand dan India lebih tinggi dibandingkan dengan Eropa dan Amenika Serikat. ${ }^{6}$ Insidens penyakit ini bervariasi antara 2 sampai 6 kasus tiap 1 juta populasi. ${ }^{1}$ Penelitian yang dilakukan The International Aplastic Anemia and Agranulocytosis Study 
di Eropa dan Israel awal tahun 1980 mendapatkan 2 kasus tiap 1 juta populasi. ${ }^{7,8}$ Perbandingan insidens antara laki-laki dan perempuan kira-kira 1:1, meskipun dari beberapa data menunjukkan laki-laki sedikit Iebih sering terkena anemia aplastik. ${ }^{8}$ Perbedaan insidens yang mungkin terjadi di beberapa tempat mungkin karena perbedaan risiko okupasional, variasi geografis dan pengaruh lingkungan. ${ }^{4,8}$ Anemia aplastik terjadi pada semua umur, dengan awitan klinis pertama terjadi pada usia 1,5 sampai 22 tahun, dengan rerata 6-8 tahun. ${ }^{5}$ Di Departemen Ilmu Kesehatan Anak FKUIRSCM, dalam kurun satu tahun (Mei 2002-Mei 2003) terdapat 9 kasus anemia aplastik, 4 anak perempuan dan 5 anak laki-laki.

\section{Patofisiologi}

Penyebab anemia aplastik sulit ditentukan, terutama karena banyak kemungkinan yang harus disingkirkan. Jika tidak ditemukan penyebab yang pasti maka digolongkan ke dalam penyebab idiopatik. ${ }^{4}$ Pendapat lain menyatakan bahwa penyebab terbanyak dari kegagalan sumsum tulang adalah iatrogenik karena kemoterapi sitostatik atau terapi radiasi. ${ }^{3,7}$

Kerusakan yang terjadi pada anemia aplastik terdapat pada sel induk dan ketidakmampuan jaringan sumsum tulang untuk memberi kesempatan sel induk untuk tumbuh dan berkembang dengan baik. Hal ini berkaitan erat dengan mekanisme yang terjadi seperti toksisitas langsung atau defisiensi selsel stromal. Penyimpangan proses imunologis yang terjadi pada anemia aplastik berhubungan dengan infeksi virus atau obat-obatan yang digunakan, atau

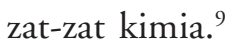

Hematopoesis normal yang terjadi di dalam sumsum tulang, merupakan interaksi antara progenitor hematopoetik stem cell dengan lingkungan mikro (microenvironment) pada sumsum tulang. Lingkungan mikro tersebut mengatur hematopoesis melalui reaksi stimulasi oleh faktor pertumbuhan hematopoetik. ${ }^{4,9}$ Sel-sel hematologik imatur dapat terlihat dengan pemeriksaan flouresent activate flow citometry, yang dapat mendeteksi sel antigen $\mathrm{CD} 34^{+}$dan adhsesi protein kurang dari $1 \%$ pada sumsum tulang normal. 3,10 Anemia aplastik dapat terjadi secara heterogen melalui beberapa mekanisme yaitu kerusakan pada lingkungan mikro, gangguan produksi atau fungsi dan faktor-faktor pertumbuhan hematopoetik, dan kerusakan sumsum tulang melalui mekanisme imunologis. ${ }^{3},{ }^{7}$

Limfosit $\mathrm{T}$ sitotoksik aktif, memegang peran yang besar dalam kerusakan jaringan sumsum tulang melalui pelepasan limfokin seperti interferon- $\alpha($ IFN- $\gamma)$ dan tumor necrosis factor $\beta$ (TNF- $\beta$ ). Peningkatan produksi interleukin-2 mengawali terjadinya ekspansi poliklonal sel T. Aktivasi reseptor Fas melalui fas-ligand menyebabkan terjadinya apoptosis sel target. Efek IFN$\gamma$ melalui interferon regulatory factor 1 (IRF-1), adalah menghambat transkripsi gen dan masuk ke dalam siklus sel. IFN- $\gamma$ juga menginduksi pembentukan nitric oxide synthase (NOS), dan produksi gas toksik nitric oxide (NO) yang mungkin menyebabkan efek toksiknya menyebar. ${ }^{3}$

\section{Diagnosis}

Diagnosis anemia aplastik ditegakkan berdasarkan keadaan pansitopenia yang ditandai oleh anemia, leukopenia dan trombositopenia pada darah tepi. ${ }^{4,5,11-13}$ Keadaan inilah yang menimbulkan keluhan pucat, perdarahan dan demam yang disebabkan oleh infeksi. Pada pemeriksaan fisik, tidak ditemukan hepatosplenomegali atau limfadenopati. Di samping keadaan pansitopenia, pada hitung jenis juga menunjukan gambaran limfositosis relatif. Diagnosis pasti anemia aplastik ditentukan berdasarkan pemeriksaan aspirasi sumsum tulang yang menunjukkan gambaran sel yang sangat kurang, terdapat banyak jaringan ikat dan jaringan lemak, dengan aplasi sistem eritropoetik, granulopoetik dan trombopoetik. ${ }^{5,13}$

\section{Prognosis}

Prognosis penyakit ini sukar diramalkan namun pada umumnya buruk, karena seperti telah dikemukakan baik etiologi maupun patofisiologinya sampai sekarang belum jelas. Sekitar dua pertiga pasien meninggal sekitar 6 bulan setelah diagnosis ditegakkan, kurang dari $10-20 \%$ sembuh tanpa transplantasi sumsum tulang dan sepertiga pasien meninggal akibat perdarahan dan infeksi yang tidak teratasi. Penyebab kematian pada umumnya adalah sepsis akibat infeksi Pseudomonas dan Stafilokokus. Oleh karena itu, menentukan prognosis pasien anemia aplastik penting karena akan menentukan terapi yang sesuai. ${ }^{4}$ 
Beberapa hal yang dapat dijadikan pedoman dalam menentukan prognosis pasien anemia aplastik adalah usia pasien, gambaran sumsum tulang hiposeluler atau aseluler, gambaran darah tepi, dan ada tidaknya infeksi sekunder.,3 Prognosis pasien anemia aplastik disebut buruk jika ditemukan pada usia muda, gambaran sumsum tulang aseluler dengan pengurangan proporsi komponen mieloid dari sumsum tulang lebih dari $30 \%$ limfosit, gambaran darah tepi dengan jumlah retikulosit $<1 \%$, leukosit $<500 / \mathrm{uL}$, dan trombosit < 20.000/uL, disertai infeksi sekunder. ${ }^{5,13}$ Di antara halhal di atas yang paling baik dijadikan sebagai pegangan dalam menentukan prognosis adalah gambaran sumsum tulang. ${ }^{13}$

\section{Masalah tata laksana anemia aplastik}

Berdasarkan patofisiologi penyakit ini, pendekatan terapi anemia aplastik terdiri dari tata laksana suportif yang ditujukan untuk mengatasi keadaan pansitopenia yang ditimbulkannya, penggantian stem cell dengan transplantasi sumsum-tulang atau penekanan proses imunologis yang terjadi dengan menggunakan obatobat imunosupresan. ${ }^{2,5}$

\section{Tata laksana suportif}

Tata laksana suportif ditujukan pada gejala-gejala akibat keadaan pansitopenia yang ditimbulkan. Untuk mengatasi keadaan anemia dapat diberikan transfusi leukocyte-poor red cells yang bertujuan mengurangi sensitisasi terhadap HLA (human leukocyte antigen), menurunkan kemungkinan transmisi infeksi hepatitis, virus sitomegalo dan toksoplasmosis, ${ }^{5}$ pada beberapa kasus mencegah graft-versus host disease (GVHD). Transfusi ini dapat berlangsung berulang-ulang sehingga perlu diperhatikan efek samping dan bahaya transfusi seperti reaksi transfusi, hemolitik dan nonhemolitik, transmisi penyakit infeksi, dan penimbunan zat besi. ${ }^{13,14}$

Perdarahan yang terjadi sering menyebabkan kematian. Untuk mencegah perdarahan terutama pada organ vital dapat dilakukan dengan mempertahankan jumlah trombosit di atas 20.000/uL. ${ }^{5,13}$ Hal ini dapat dilakukan dengan transfusi suspensi trombosit. Perlu diingat bahwa pemberian suspensi trombosit dapat menyebabkan keadaan isoimunisasi apabila dilakukan lebih dari 10 kali, dan keadaan ini dapat mempengaruhi keberhasilan terapi. ${ }^{13}$ Isoimunisasi dapat dicegah dengan pemberian trombosit dengan HLA yang kompatibel dengan pasien. Bila perdarahan tetap terjadi dapat ditambahkan antifibrinolisis. ${ }^{3,5}$

Untuk mengatasi infeksi yang timbul karena keadaan leukopenia, dapat diberikan pemberian antibiotik profilaksis dan perawatan isolasi. Kebersihan kulit dan perawatan gigi yang baik sangat penting, karena infeksi yang terjadi biasanya berat dan sering menjadi penyebab kematian. ${ }^{5,12}$ Pada pasien anemia aplastik yang demam perlu dilakukan pemeriksaan kultur darah, sputum, urin, feses, dan kalau perlu cairan serebrospinalis. Bila dicurigai terdapat sepsis dapat diberikan antibiotik spektrum luas dengan dosis tinggi secara intravena dan kalau penyebab demam dipastikan bakteni terapi dilanjutkan sampai 10-14 hari atau sampai hasil kultur negatif. ${ }^{12}$ Bila demam menetap hingga 48 jam setelah diberikan antibiotik secara empiris dapat diberikan anti jamur. ${ }^{15,16}$

Pada tata laksana anemia aplastik, yang tidak kalah penting adalah penghindaran dari bahan-bahan fisika maupun kimiawi, termasuk obat-obatan yang mungkin menjadi penyebab. Bila zat-zat kimia atau fisika yang bersifat toksik itu ditemukan dan masih terdapat dalam tubuh, harus diusahakan untuk mengeluarkannya walaupun hal ini kadang tidak dapat dilakukan. ${ }^{4,5,13}$

\section{Tata laksana medikamentosa}

\section{Obat-obatan}

Tata laksana anemia aplastik dengan obat-obatan diberikan pada pasien anemia aplastik derajat ringan, pasien yang tidak mendapatkan donor yang sesuai untuk transplantasi, dan pasien yang mempunyai kontra-indikasi untuk dilakukan transplantasi sumsum tulang. ${ }^{5}$ Tujuan pemberian obat-obatan untuk mengurangi morbiditas, mencegah komplikasi, dan eradikasi keganasan. ${ }^{17}$

\section{Androgen}

Androgen digunakan sebagai terapi anemia aplastik sejak tahun 1960. Efek androgen dalam tata laksana anemia aplastik untuk meningkatkan produksi eritropoetin dan merangsang sel stem eritroid. 
Penggunaan androgen tunggal sebagai terapi anemia aplastik ternyata tidak meningkatkan angka kesintasan pada pasien. Penelitian yang dilakukan di Amerika Serikat, androgen sebagai tambahan terapi antitymocyte globulin (ATG) juga tidak menunjukkan keuntungan, sedangkan penelitian yang dilakukan di Eropa menunjukkan androgen hanya meningkatkan respons hematologi tetapi tidak meningkatkan angka kesintasan. ${ }^{2}$ Terapi androgen pada pasien anemia aplastik yang gagal dengan terapi imunosupresan mungkin berguna, meskipun berbahaya. Preparat androgen yang sering digunakan adalah metil testosteron, testosteron enantat, testosteron propionat, oksimetolon dan etiokolanolon. Dosis yang digunakan adalah $2-5 \mathrm{mg} /$ $\mathrm{kg}$ berat badan/minggu, secara intramuskular. Dosis nandrolon dekanoat diberikan $5 \mathrm{mg} / \mathrm{kg}$ berat badan / minggu. ${ }^{11,12}$ Efek samping yang dapat timbul dari pemberian preparat androgen ini seperti kolestasis, hepatomegali, tumor hepar, maskulinisasi, kebotakan, dan pembesaran alat kelamin. Pasien dengan terapi androgen sebaiknya dilakukan pemeriksaan fungsi hati secara berkala, pemeriksaan ultrasonografi hati setiap tahun, dan pemeriksaan usia tulang per tahun. ${ }^{4,15}$

\section{Imunosupresan}

\section{Metilprednisolon}

Beberapa penelitian menunjukkan bahwa metilprednisolon dosis rendah $2-4 \mathrm{mg} / \mathrm{kg}$ berat badan /hari, dapat digunakan untuk mengurangi perdarahan dan gejala serum sickness. Metilprednisolon dosis tinggi memberikan respons pengobatan yang baik sampai $40 \%{ }^{4,17}$ Dosis metilprednisolon adalah $5 \mathrm{mg} / \mathrm{kg} /$ berat badan secara intravena selama 8 hari kemudian dilakukan tappering dengan dosis $1 \mathrm{mg} / \mathrm{kg}$ berat badan /hari selama 9-14 hari, lalu tappering selama 15-29 hari. Pemakaian kortikosteroid dibatasi pada keadaan antilimfosit globulin tidak tersedia atau terlalu mahal. Efek samping antara lain ulkus peptikum, edem, hiperglikemia, dan osteonekrosis. ${ }^{17}$

\section{Antilimfosit globulin (ALG)}

Antilimfosit globulin adalah sitolitik sel $\mathrm{T}$ yang bersama dengan siklosponin berperan dalam menghambat fungsi sel $\mathrm{T}$, khususnya dalam produksi limfokin-limfokin supresif. ${ }^{4,11,17}$ Pemberian ALG secara cepat akan mengurangi limfosit dalam sirkulasi sehingga berkurang $10 \%$, dan ketika limfosit total kembali normal berarti limfosit $\mathrm{T}$ aktif jumlahnya berkurang. Sediaan ALG invitro merangsang proliferasi sel $\mathrm{T}$ dan mempromosikan sekresi beberapa faktor pertumbuhan. ${ }^{4,11,17}$ Antilimfosit globulin dapat diberikan dengan dosis $40 \mathrm{mg} / \mathrm{kg}$ berat badan /hari selama 12 jam dilanjutkan dengan infus yang dikombinasikan dengan metilprednisolon $1 \mathrm{mg} / \mathrm{kg}$ berat badan /hari intravena selama 4 hari. Dapat juga diberikan dosis $20 \mathrm{mg} / \mathrm{kg}$ berat badan /hari selama 4-6 jam dengan infus intravena selama 8 hari berturutturut yang dikombinasikan dengan prednison $40 \mathrm{mg} /$ $\mathrm{m}^{2} /$ hari selama 5 hari dimulai pada hari terakhir pemberian ALG. ALG dapat menyebabkan perasaan panas dingin, kemerahan, trombositopenia dan serum sickness. Keberhasilan terapi menggunakan ALG tunggal sekitar $50 \% .^{5}$

\section{Antitymocyt Globulin (ATG)}

Antitymocyt Globulin menghambat mediasi respons imun dengan mengubah fungsi sel $\mathrm{T}$ atau menghilangkan sel reaktif antigen. Dosis yang diberikan 100$200 \mathrm{mg} / \mathrm{kg}$ berat badan intravena. Kontraindikasi ATG adalah reaksi hipersensitivitas, keadaan leukopenia dan atau trombositopenia. ${ }^{17}$ Penelitian yang membandingkan hasil akhir antara tata laksana anemia aplastik dengan ATG dan transplantasi sumsum tulang (TST) dilaporkan bahwa pada 155 pasien anemia aplastik dewasa yang diterapi dengan TST lebih baik dibandingkan dengan penggunaan ATG tunggal sesuai protokol terbaru. ${ }^{18}$ The European blood and marrow transplant severe anemia aplastic working party melakukan penelitian pada pasien anemia aplastik tidak berat, yang diberikan terapi imunosupresan. Disimpulkan bahwa penggunaan kombinasi ATG dan siklosporin A lebih baik daripada siklosporin A tunggal dalam kelompok respons hematologi, kualitas respons dan kematian awal. ${ }^{19}$

\section{Siklosporin A (Cs A)}

Merupakan cyclic polypeptide yang menghambat imunitas humoral, sebagai inhibitor spesifik terhadap sel limfosit T, mencegah pembentukan interleukin-2 dan interferon- $y .{ }^{4,5,11}$ Dan dapat menghambat reaksi imun seperti penolakan jaringan transplan, GVHD, dan lain-lain. Dosis awal dapat diberikan $8 \mathrm{mg} / \mathrm{kg}$ berat 
badan /hari peroral selama 14 hari dilanjutkan dengan dosis $15 \mathrm{mg} / \mathrm{kg}$ berat badan /hari pada anak-anak dan $12 \mathrm{mg} / \mathrm{kg} / \mathrm{hari}$ pada dewasa. Dosis kemudian dipertahankan pada kadar 200-500ug/L untuk menghindari efek toksik. Bila ditemukan efek toksik, terapi dihentikan 1-4 hari untuk kemudian dilanjutkan dengan dosis yang lebih rendah. Respons terapi dengan siklosporin tunggal hanya sekitar 25\%. Kombinasi siklosporin dengan ATG meningkatkan kecepatan remisi sistem hematopoetik sekitar 70\%.,12

\section{Siklofosfamid (CPA)}

Penggunaan siklofosfamid sebagai terapi anemia aplastik, dimulai pada saat penggunaan siklofospamid sebagai persiapan transplantasi sumsum tulang. ${ }^{4}$ Siklofosfamid (CPA) adalah zat kimia yang berkaitan dengan nitrogen mustard. Sebagai agen alkali CPA terlibat dalam cross-link DNA yang mungkin berhubungan dengan pertumbuhan sel normal dan neoplasma. ${ }^{17}$ Sejumlah peneliti menyatakan dosis terapi yang diberikan adalah $50 \mathrm{mg} / \mathrm{kg}$ berat badan / hari selama 4 hari berturut-turut. Tetapi perlu diingat dosis tinggi yang diberikan akan meningkatkan efek tosik yang serius dan efek terapi yang ditimbulkan tidak lebih baik dibandingkan dengan terapi kombinasi. ${ }^{20}$ Penelitian yang dilakukan terhadap 10 pasien anemia aplastik berat dengan CPA $45 \mathrm{mg} / \mathrm{kg}$ berat badan /hari selama 4 hari, memberikan hasil lebih efektif dibandingkan dengan imunosupresan konvensional lainnya, dalam hal memperbaiki hematopoesis normal dan pencegahan relaps atau kelainan-kelainan klonal sekunder, meskipun tanpa dilakukan TST. ${ }^{21}$ Penelitian yang dilakukan terhadap 19 pasien yang diberikan CPA dengan dosis $50 \mathrm{mg} / \mathrm{kg}$ berat badan /hari selama 4 hari didapatkan hasil terapi CPA dosis tinggi tanpa TST membuat remisi bebas pada pasien anemia aplastik berat. Penelitian ini dilakukan pada pasien yang tidak dapat dilakukan transplantasi sumsum tulang. ${ }^{20}$

\section{Faktor-faktor pertumbuhan hemato- poetik (growth factors)}

Dari beberapa penelitian, pemberian cytokines dapat menyebabkan perbaikan jumlah neutrofil dan juga meningkatkan angka kesintasan, meskipun jika digunakan berkepanjangan dapat meningkatkan risiko penyakit klonal. Dari penelitian, penggunaan recombinant human granulocyte-macrophage stimulating factor (GM-CSF) dengan dosis $8-32 \mathrm{ug} / \mathrm{kg} / \mathrm{hari}$ intravena yang dikombinasikan dengan siklosponin $\mathrm{A}$ dan ALG dapat meningkatkan jumlah sel-sel darah di perifer maupun di sumsum tulang. Keadaan ini bersifat sementara atau menetap yang ditandai dengan respon klinis terhadap infeksi. Pasien dengan jumlah granulosit awal lebih banyak memberikan respon terapi yang lebih baik, diduga karena meningkatnya cadangan sel prekursor mieloid di sumsum tulang. Jangan diberikan setelah 24 jam pemberian sitostatik karena dapat meningkatkan sensitivitas. ${ }^{2,17}$

Dapat juga diberikan recombinat human granulocyte colony stimulating factor (G-CSF) yang dapat mengaktifkan dan menstimulasi produksi, stimulasi, migrasi dan sitotoksisitas dan neutrofil. Dosis yang dapat diberikan $5 \mathrm{ug} / \mathrm{kg}$ berat badan /hari subkutan. Efek samping yang dapat terjadi, risiko untuk berkembang menjadi sindrom mielodisplastik atau leukemia mieloid akut. Human IL-3 dengan dosis sampai 1000 $\mathrm{ug} / \mathrm{m} 2 /$ hari juga dapat merangsang aktivitas sistem hematopoetik bila diberikan bersama faktor pertumbuhan yang lain. Faktor pertumbuhan ini merupakan terapi tambahan pada anemia aplastik yang dengan infeksi, dan berguna pada pasien anemia aplastik berat karena stem cell pada sumsum tulang yang sangat kurang. ${ }^{2,12,17}$ Penelitian yang mempelajari efek GMCSF, IL-3, IL-6, dan G-CSF didapatkan G-CSF mempunyai efek yang paling baik dalam memperbaiki respons hematopoesis. ${ }^{22}$

\section{Terapi obat kombinasi}

Kombinasi obat-obat imunosupresan pada terapi pasien anemia aplastik hasilnya Iebih memuaskan dibandingkan dengan imunosupresan tunggal. Kombinasi ALG, metilprednisolon dan siklosporin A menghasilkan remisi parsial atau total sebesar $65 \%{ }^{5,23}$ Kombinasi lain antara ATG, siklosporin A dan G-CSF dilaporkan memberikan respon hematopoetik yang memuaskan dengan penurunan angka kematian. Penelitian yang dilakukan Stephen Rosenfeld dkk, dengan metode kohort pada 122 pasien yang diberikan $40 \mathrm{mg} / \mathrm{kg}$ berat badan /hari dengan ATG selama 4 hari dan $10-12 \mathrm{mg} / \mathrm{kg}$ berat badan /hari, siklosporin A selama 6 bulan dan pemberian jangka pendek kortikosteroid didapatkan kurang lebih setengah dan 
pasien anemia aplastik berat mempunyai waktu penyembuhan yang lebih baik dengan hasil jangka panjang yang memuaskan. ${ }^{15,24}$

Penelitian terbaru yang mengkombinasikan ATG dengan siklosporin pada pasien anemia aplastik berat didapatkan hasil peningkatan angka kesintasan 7 tahun yang memuaskan pada $55 \%$ kasus. ${ }^{32}$ Kombinasi ATG dan CsA merupakan terapi imunosupresan lini pertama untuk pasien dengan anemia aplastik berat. ${ }^{25,26}$

\section{Transplantasi sumsum tulang (TST)}

Transplantasi sumsum tulang pada kasus anemia aplastik berat pertama kali dilakukan pada tahun 1970 . Sayangnya hanya $25-30 \%$ pasien yang mendapatkan donor yang diharapkan. ${ }^{2,5}$ Pengobatan anemia aplastik dengan transplantasi sumsum tulang meningkatkan angka kesintasan sekitar 60-70\%. Pasien berusia muda tanpa transfusi berulang mempunyai respon yang lebih baik lagi sekitar $85-95 \%$ karena limfosit pasien tersebut belum tersensitisasi oleh paparan antigen sebelumnya. ${ }^{4,11}$ Dari sebuah penelitian yang dilakukan pada 1305 pasien didapatkan angka kesintasan 5 tahun meningkat dan $48 \% \pm 7 \%$ pada tahun $1976-1980$ menjadi $66 \% \pm 6 \%$ pada tahun $1988-1992(\mathrm{p}<0,0001)$. Risiko terjadinya graft-versus-host-disease (GVHD) dan pneumonia interstisial menurun tetapi risiko terjadinya penolakan jaringan transplan tidak. ${ }^{27}$ Penelitian lain yang dilakukan terhadap 212 pasien anemia aplastik didapatkan bahwa TST menyebabkan hematopoesis menjadi normal dengan penyebab morbiditas dan mortalitas yang utama akibat GVHD kronik. ${ }^{28}$ Penelitian yang dilakukan terhadap 6.691 pasien yang dilakukan TST alogenik temyata kemungkinan dapat sembuh lebih besar, meskipun beberapa tahun setelah TST mortalitasnya lebih tinggi dibandingkan populasi normal. ${ }^{29}$

Sulitnya mencari donor yang sesuai dengan pasien, dapat diatasi dengan TST yang berasal dan cord blood; dan penelitian yang dilakukan terhadap 78 pasien yang mendapat TST cord blood dan donor yang related, dan 65 pasien yang dilakukan TST dengan donor unrelated, disimpulkan bahwa cord blood adalah altematif yang mungkin sebagai sumber sel induk untuk TST pada anak-anak dan dewasa dengan kelainan hematologis mayor, terutama jika donor dan recipient related. ${ }^{30}$

Komplikasi TST yang paling sering terjadi adalah GVHD, graft failure dan infeksi. Penelitian retrospektif yang dilakukan Min CK, dan kawan-kawan terhadap 40 pasien anemia aplastik yang dilakukan TST alogenik didapatkan insidens graft failure, GVHD akut, GVHD kronis masing-masing 22,5\%, 12,8\% and 23,1\%. sedangkan $5 \%$ pasien mengalami pneumonia interstisial dan $2,5 \%$ pneumonia. ${ }^{31}$

\section{Efek jangka panjang pada pengobatan anemia aplastik}

Pengobatan anemia aplastik baik dengan TST maupun dengan penggunaan imunosupresan menimbulkan efek jangka panjang pada pasien. Pasien yang mampu bertahan hidup akan berisiko terkena keganasan. Angka kejadian sindrom mielodisplasia dan leukemia akut lebih tinggi dibandingkan dengan TST. (Tabel 1) Dari laporan penelitian-penelitian yang telah dilakukan, dampak jangka panjang terapi anemia aplastik mempunyai risiko yang tinggi untuk terjadi tumor padat, sindrom mielodisplastik dan leukemia akut setelah terapi TST dan imunosupresan., ${ }^{5,32}$

Tabel 1. Efek jangka panjang pengobatan anemia aplastik

\begin{tabular}{lcc}
\hline $\begin{array}{c}\text { Dampak jangka panjang } \\
\text { (kumulatif dalam 10 tahun) }\end{array}$ & $\begin{array}{c}\text { Terapi } \\
\text { imunosupresan (\%) }\end{array}$ & $\begin{array}{c}\text { Transplantasi } \\
\text { sumsum tulang (\%) }\end{array}$ \\
\hline Jumlah pasien kanker & 18,8 & 3,1 \\
Sindrom mielodisplasia & 9,6 & 0,0 \\
Leukemia akut & 6,6 & 0,25 \\
Tumor padat & 2,2 & 2,9 \\
\hline
\end{tabular}

dilaporkan oleh European Bone Marrow Tranplantation-Severe Aplastic Anemia 


\section{Daftar Pustaka}

1. Young NS. Acquired aplastic anemia. Ann Intern Med 2002;136. h. 534-46

2. Young NS, Barrett AJ. The treatment of severe acquired aplastic anemia. Blood 1995;85:3367-77.

3. Young NS, Maciejewski J. The pathofisiology of acquired aplastic anemia. N engl J Med 1997;336:1365-72.

4. Alter BP, Young NS. The bone marrow failure syndromes. Dalam: Nathan DG, Oski FA, penyunting. Hematology of infancy and childhood. Edisi ke-4. Philadelphia: Saunders, 1993. h. 216-37.

5. Lanzkowsky P. Bone marrow failure. Manual of pediatric hematology and oncology. Edisi ke-2. New york: Churchill Livingstone, 1995. h. 89-96.

6. Gordon Smith EC. Epidemiology and aetiology of aplastic anemia. Disampaikan pada kongres Intemasional society of haematology Asian Pasifik, Bangkok, 25-29 Oktober, 1999.

7. Young NS. Acquired aplastic anemia. JAMA 1999; 282:271-8.

8. Issaragrisil S. Aplastic anemia: Epidemiology. Disampaikan pada kongres Internasional society of haematology Asian Pasifik. Bangkok, 24-28 Oktober, 1999.

9. Lipton JM. The hematopoetic garden: how does it grow? J pediatr 1998;132:565-7.

10. Sloand S, Kim S, Tidsale J, dkk. Intracelluler interferon$\mathrm{g}$ in circulating and marrow $\mathrm{T}$ cells detected by flow cytometry and the response to immunosuppressive therapy in patients with aplastic anemia. Blood 2002; 100:1185-91.

11. Shadduck RK. Aplastic anemia. Dalam : Beutler E, Lietcman MA, Coller BS, dkk, penyunting. Wiliams hematology. Edisi ke-5. New York:McGraw Hill, 1995. h. 238-51.

12. Young NS. Aplastic anemia. Dalam: Brain MC, Carbone PP. Kelton JG, Schiler JH, penyunting. Current therapy in hematology-oncology. Edisi ke-5. St. Lois: Mosby, 1995. h. 129-34.

13. Munthe BG. Diagnostik dan penanggulangan anemia aplastik. Dalam: Pendidikan tambahan berkala Ilmu Kesehatan Anak. FKUI-RSCM Jakarta 1991. h. 33-40.

14. Gatot D. Penatalaksanaan transfusi pada anak. Dalam: Update emergencies pediatrics. Jakarta : Balai Pustaka FKUI 2002. h. 28-47.

15. Fonseca R, Tefferi A. Practical aspect of diagnosis and management of aplastic anemia. Am J Med Sci 1997; 28:129-34.
16. Speck B, Nissen C, Tichelli A, Gratwohl A. aplastic anemia: treatment. Disampaikan pada kongres Internasional Society of Haematology, Singapore, 25-29 Agustus, 1996.

17. Bakhshi S. Aplastic anemia. E-medicine journal; 2002. Didapat dari: www.emedicine.com. Di akses tanggal 12 Pebruari 2003.

18. Paquete RL, Tebyani N, Frane M, dkk. Long-term outcome of aplastic anemia in adults treated with antithymocyte globulin: Comparison with bone marrow transplantation. Blood 1995;85:283-90.

19. Marsh J, Schrezenmeier H, Marin P. Prospective randomized study comparing cyclosponine alone versus the combination of antithymocite globulin and cyclosporine for treatment of patients with nonsevere aplastic anemia: A report from the European blood and marrow transplantation (EBMT) severe aplastic anemia working party. Blood 1999;93:2191-5.

20. Brodsky RA, Sensenbrenner LL, smith BD, Dorr D, Seaman DJ, Lee SM. Durable treatment-free remission after high-dose cyclophosphamid therapy for previously untreated severe aplastic anemia. Ann intern Med. 2001;87:477-83.

21. Broadsky RA, Sensenbrenner LL, Jones RI. Complete remission in severe aplastic anemia high-dose cyclophospamid without bone marrow transplantation. Blood 1996;87:491-4.

22. Scopes J, Daly S, Atkinson R. Aplastic anemia: evidence for dysfunctional bone marrow progenitor cells and the corrective effect of Granulocyte colony stimulating factor in vitro. Blood 1996;87:3179-85.

23. Frickhofen N, Kaltwasser JP, Schrezenmeier H, Ragha Vaghar A, Vogt HG, Herrmann F. Treatment of aplastic anemia with antilymphocyte globulin and methylprednisolone with or without cyclosporine. $\mathrm{N}$ engl J Med 1991;324:1298-303.

24. Bacigalupo N, kaltwasser JP, Corda G, Arcese W, Carotenuto W, Gallamini W. Antilymphocyte globulin, cyclosporin and granulocyte colony stimulating factors in patients with acquired aplastic anemia. Blood 1995;324:1298-303

25. Rosenfeld S, Follmann D, Nunez O. Antythymocyte globulin and cyclosporine for severe aplastic anemia association between hematologic response and long-term outcome. JAMA 2003;289:1130-5.

26. Rosenfeld SJ, Kimball J, Vining D. Intensive immunosupression with antithymocyte globulin and Cyclosporin as treatment for severe acquired aplastic anemia. Blood 1995;85:3058-65.

27. Passweg JR, Socie G, Hinterberger W. Bone marrow transplantation for severe aplastic anemia: has outcome improved?. Blood 1997;90:858-64. 
Sari Pediatri, Vol. 7, No. 1, Juni 2005

28. Deeg HJ, Leisenring W, Rainer S, Nimms D, Flower M, Sandrers J. Long-term outcome after marrow transplantation for severe aplastic anemia. Blood 1998;91:3637-45.

29. Socie G, Stone JV, Wingard JR. long-term survival and late deaths after allogeneic bone marrow transplantation. N engl J Med 1991;341:14-21.

30. Gluckmann E, Rocha V, Boyer-Chammard A. Outcome of cord-blood transplantation from related and unrelated donors. N engl J Med 1997; 337:373-81.
31. Min CK, Kim DW, Lee JW, Han CW, Min WS, Kim CC. Hematopoetic stem cell transplantation og high risk adult patient with severe anemia aplastic; reduction of graft failure by enhanching stem cell dose. Haematologica 2001;86:303-10.

32. Socie G, Henry-Amar M, Bacigalupo A, Hows J, Tichelli A, Ljungman P. malignant tumors occurring after treatment of aplastic anemia. $\mathrm{N}$ engl J Med 1993; 329:1152-7. 